University of Nebraska - Lincoln

DigitalCommons@University of Nebraska - Lincoln

Faculty Publications: Agricultural Leadership, Education \& Communication Department
Agricultural Leadership, Education \& Communication Department

April 1990

\title{
EFFECTS OF SIMULATION ON COGNITIVE ACHIEVEMENT IN AGRICULTURE M ECHANICS
}

\author{
David M. Agnew \\ University of Nebraska - Lincoln \\ Glen C. Shinn \\ Clemson University
}

Follow this and additional works at: https://digitalcommons.unl.edu/aglecfacpub

Part of the Other Public Affairs, Public Policy and Public Administration Commons

Agnew, David M. and Shinn, Glen C., "EFFECTS OF SIMULATION ON COGNITIVE ACHIEVEMENT IN AGRICULTURE M ECHANICS" (1990). Faculty Publications: Agricultural Leadership, Education \& Communication Department. 4.

https://digitalcommons.unl.edu/aglecfacpub/4

This Article is brought to you for free and open access by the Agricultural Leadership, Education \& Communication Department at DigitalCommons@University of Nebraska - Lincoln. It has been accepted for inclusion in Faculty Publications: Agricultural Leadership, Education \& Communication Department by an authorized administrator of DigitalCommons@University of Nebraska - Lincoln. 


\section{EFFECTS OF SIMULATION ON COGNITIVE ACHIEVEMENT IN AGRICULTURE MECHANICS}

\section{David M. Agnew, Assistant Professor}

University of Nebraska-Lincoln

\section{Glen C. Shinn, Professor and Head Clemson University}

Teachers constantly face the decision of how to design instruction which will best meet the needs of the learner. These decisions include selecting methods and techniques. The selection process requires not only that the teacher be aware of how to use various techniques, but that he/she know which types of students learn best with various techniques, which techniques should be used under various conditions and what levels or types of information can best be learned using various techniques.

Olivas and Newstrom (1981) stated that the effectiveness of the methods depends upon the particular objective being served. When selecting techniques or methods, it is good to remember the basic principles of learning, and if possible, select techniques which incorporate those principles. A comprehensive list of the principles of learning is provided by Newcomb, McCracken and Warmbrod (1986). Perhaps the oldest and most well known principle is the principle of learning by doing Simulation usually includes this principle by providing higher levels of participation to the learner than other techniques (Olivas and Newstrom, 1981). Spitze's (1980) taxonomy of teaching techniques is based upon the principle of decreasing reality. It starts with real life situations, followed by simulation of reality, and last by abstractions from reality. Real life situations are not always possible due to safety and logistical concerns. Therefore, the next best alternative in some situations is simulation (Spitze, 1980). Another commonly stated advantage of simulation is the safety of learning or practicing new information of skills that would be dangerous in real life. Lee (1979) also identified safety as a factor to consider in selecting a method/technique. Maidment and Bronstein (1973) agree starting at least three advantages of simulation, all of which are consistent with the commonly agreed upon principles of learning referred to by Newcomb, McCracken and Warmbrod (1986). There are many factors to consider in selecting a technique. According to Olivas and Newstrom (1981), the extent to which simulation is effective will depend in part upon the style of simulation used; however, for including the principles active participation and practice, simulation is very effective.

According to McClelland (1970), both the military and industrial sectors have recognized simulation as an effective teaching technique and have made extensive use of it in their training programs with satisfactory results. McClelland recommended that vocational teachers not postpone the use of simulation because of a lack of empirical data. Since McClelland made this statement, considerable research has been conducted. However, due to the diversity of simulations and the nature of the research conducted, findings have not been conclusive. The purpose of this study was to examine the effectiveness of simulation as a technique of instruction and to add to the empirical database necessary for decision making.

\section{Purposes and Objectives}

The primary purposes were to compare the effect of a simulation technique to the conventional technique of instruction on student learning and retention of low-level and high-level cognitive information. This study sought to answer two questions:

1. To what extent will cognitive achievement be affected by the instructional technique as measured by an immediate posttest?

2. To what extent will cognitive achievement be affected by instructional technique as measured by a delayed posttest?

The following hypotheses were tested at $\mathbf{p}<.05$. The significance level was present at the .05 alpha level.

$\mathrm{H} \mathrm{d}$ : There is no significant difference between the immediate cognitive achievement test scores (CP 1) of the two treatment groups when both techniques are administered by the same teachers with mechanical aptitude test scores used as the covariate. 
$\mathrm{H}$ 2: There is no significant difference between the immediate low-level cognitive achievement test scores of the two treatment groups when both techniques are administered by the same teachers with mechanical aptitude test scores used as the covariate.

$\mathrm{H}$ 3: There is no significant difference between the immediate high-level cognitive achievement test scores ( $\mathrm{CP}$ 1) of the two treatment groups when both techniques are administered by the same teachers with mechanical aptitude test scores used as the covariate.

$\mathrm{H}$ \&: There is no significant difference between the delayed cognitive achievement test scores (CP

2) of the two treatment groups when both techniques are administered by the same teachers with mechanical aptitude test scores used as the covariate.

H 5: There is no significant difference between the delayed low-level cognitive achievement test scores (CP 2) of the two treatment groups when both techniques are administered by the same teachers with mechanical aptitude test scores used as the covariate.

H 6: There is no significant difference between the delayed high-level cognitive achievement test scores (CP 2) of the two treatment groups when both techniques are administered by the same teachers with mechanical aptitude test scores used as the covariate.

Hypotheses one, two, and three were concerned with immediate cognitive achievement with Mechanical Aptitude (MA) test scores used as the covariant. Hypotheses four, five and six were concerned with delayed cognitive achievement using MA test scores as the covariate. For each hypothesis there were two subhypotheses which dealt with each subject matter; dc electricity and hydraulics.

\section{Procedure}

This experimental study used a randomized control-group posttest only design (Isaac and Michael, 1983) to examine the dependent variables. The dependent variables were student scores on the immediate and delayed cognitive posttests. The independent variables were instructional technique and time of testing. Two-stage random assignment was used to place the schools into the two study groups. The treatment groups were taught the subject matter using simulation. The conventional group received instruction using the actual $\mathrm{dc}$ electrical or hydraulic tractor components. The sequence of activities for each group, treatment and conventional, is shown in Figure 1. The sample was drawn from the population of students enrolled in Mississippi public secondary vocational and agriculture programs classified, by the State Department of Education in 1982, as specialized agricultural mechanics programs. A total of 246 students from 12 schools were selected to participate in the study. However, data from 230 students and 11 schools were available for final analysis.

The cognitive achievement tests and instructional materials, developed by the researchers, were field tested with 34 vocational agriculture students at West Marion County High School in Foxworth, Mississippi, in May of 1984, and by a group of nine Ford tractor mechanics in June of 1984. The test was also reviewed by a group of agriculture instructors that participated in an inservice workshop in agricultural mechanics. Also, a Ford area Service Representative reviewed the tests and provided input to insure content validity. The test was reviewed by three faculty on campus to insure design validity. Based on these reviews and field tests, instructional materials and test items were modified for final use with the sample population.

To control for threats to internal validity, all treatments were- started on a Monday and completed in five days, only classes with first year (mostly juniors) students were included; a strict teaching outline was provided, and only students that were present for three or more of the five days of the treatment could be included in the testing. Teachers were asked not to teach about dc electricity and hydraulics before the experiment or during the one week delay between the instruction of each subject matter. All tests were mailed to the researcher and scored by machine.

Teachers from the schools randomly selected were contacted by mail and asked to participate. All instructors taught agricultural mechanics in specialized programs and were provided a special inservice activity to explain how to use the instructional and test materials. Some teachers were visited on site as needed, and others were contacted by phone or mail to respond to questions or concerns. Teachers that did not feel that their technical knowledge or ability of the subject matters was adequate, were. replaced by randomly selected schools that had a teacher capable of teaching 
the two subjects. An instructor's manual was provided to guide the teacher through the experiment. Each treatment took 5 school days (10 clock hours) to complete. Data collection (not including the administration of the MA test) and treatment spanned a 'I-week time period.

Six schools were randomly assigned to the simulation treatment. The remaining six schools used the technique involving a power train unit or tractor. All schools taught dc electricity first. Both groups completed their treatments and, after 1 week of nonrelated instruction to prevent contamination, used the alternate technique with hydraulics.

Students in the conventional group received instruction and explanation using the power train or tractor. They did not have hands-on experience but were shown the location, sequence, and function of the components on the power train or tractor. Students in the simulation group did not use a power train or tractor; these students used a simulation activity. The simulation involved the use of a set of schematic symbols on 3" $\mathrm{x}$ " " cards connected together by color coded wire connectors to form a specific hydraulic or dc electrical system as defined by an activity sheet.

Immediate cognitive achievement for each subject matter was measured by a 50 item cognitive posttest one (CP 1), and delayed cognitive achievement was measured by cognitive posttest two (CP 2), which was administered three weeks later. CP 1 and CP 2 were identical for each subject matter area; dc electricity and hydraulics. CP 1 was administered 1 to 3 days following the treatment. The reliability coefficients for the hydraulics CP 1 ranged from .61 to .93 , with only one exception of a 31. The school which had the .31 reliability coefficient, did not complete CP 2 , however, the mechanical aptitude data and the $\mathrm{CP} 1$ test scores were used in the final data analysis. The coefficients for the hydraulics CP 2 ranged from .68 to .94 . On the dc electricity posttests the reliability coefficients ranged from .79 to .90 for $\mathrm{CP} 1$ and from .64 to .92 for $\mathrm{CP} 2$. Out of a possible 50 points, the dc electricity $\mathrm{CP} 1$ scores ranged from 5 to 47 for the hydraulics $\mathrm{CP} 1$ the scores ranged and from 2 to 49 for individual subjects. Low-level and high-level cognitive questions on the posttests were identified by three experts. For a question to be classified as low-level, it had to be identified as knowledge, comprehension or application in Bloom's taxonomy (Bloom, 1957). The remaining high-level questions were in the analysis, synthesis, or evaluation levels.

Student MA test scores on the Science Research Associate's (SRA) Test of Mechanical Concepts (Stanard and Bode, 1976) were used as the covariate. The Armed Services Vocational Aptitude Battery was selected and approved for use in the study. However, due to the military's problem in scheduling the administration of the aptitude test before the treatment, an alternative test was selected and used after the treatment.

A nested or hierarchal statistical design with school nested within method was used to analyze the data. Kennedy (1978) recommended that by nesting a variable, the variable could he better estimated and controlled. School was the nested variable since students were selected as intact groups by school. Analysis of covariance, with MS test scores used as the covariate, was used to test each hypothesis.

\section{Results}

For hypotheses one, two and three there was no significant difference in the immediate cognitive achievement scores for the two techniques of instruction when MA test scores were used as the covariate. The same was true for hypotheses four, five and six in testing for a significant difference in delayed cognitive achievement scores, using MA test scores as the covariate. This was true for both subject matters (Table 1).

\section{Conclusions}

There were no statistically significant differences in the conventional or simulation technique of instruction when immediate (CP 1) or delayed ( $\mathrm{CP} 2$ ) cognitive posttest achievement scores were used as the basis for comparison. Therefore, simulation can he considered as effective an instructional technique as the use of the conventional realia. The positive results with simulation are in harmony with finding from Cherryholmes (1966), Hienkel (1970), McClelland (1970), Cohen and Brandley (1978), Pierfy (1977) and Perritt (1981). However, these findings are not consistent with the findings of Abrams (1974) and Adams (1976). From the findings of this study, simulation can be effectively used to deliver cognitive information related to basic dc electricity or hydraulics with no significant difference in student cognitive achievement as the result. 

$\mathrm{H}_{\underline{\mathrm{O}}}$ Subject
$\mathbf{M}^{2}$
Sign. E
Crit. $\underline{\text { F }}$

\begin{tabular}{llrlll}
$\mathrm{I}$ & $\mathrm{E}$ & 528.74 & 0.68 & .44 & 5.59 \\
2 & $\mathrm{H}$ & 324.10 & 0.19 & .67 & 5.32 \\
& $\mathrm{E}$ & 491.84 & 0.78 & .41 & 5.59 \\
3 & $\mathrm{H}$ & 139.55 & 0.14 & .72 & 5.32 \\
& $\mathrm{E}$ & 0.39 & 0.04 & .85 & 5.59 \\
4 & $\mathrm{H}$ & 42.26 & 0.50 & .50 & 5.32 \\
& $\mathrm{E}$ & 493.73 & 0.43 & .54 & 5.99 \\
5 & $\mathrm{H}$ & 1940.16 & 2.30 & .18 & 5.99 \\
& $\mathrm{E}$ & 518.73 & 0.51 & .50 & 5.59 \\
6 & $\mathrm{H}$ & 928.53 & 1.84 & .22 & 5.99 \\
& $\mathrm{E}$ & 1.17 & 0.23 & .65 & 5.99 \\
& $\mathrm{H}$ & 928.53 & 1.84 & .22 & 5.99 \\
\hline
\end{tabular}

Note. $\mathrm{E}=\mathrm{dc}$ Electricity, $\mathrm{H}=$ Hydraulics.

The lack of significant differences in the cognitive test scores of students should be viewed as a positive indication of the effectiveness of simulation as an instructional technique. Simulation may be used when realia is not available to teach the basic principles of dc electricity or hydraulics. The cost of producing the simulation activity in this study was approximately $\$ 25.00$ per class of 20 students. The alternative would be to incorporate a tractor or power train unit into the instructional unit. The cost and availability of such equipment could be a deterrent to instruction in some programs.

For learning the basic cognitive concepts, and the basic principles of troubleshooting for the subject of dc electricity and hydraulics, simulation activities can provide students with basic knowledge and understanding. The development of motor skills and proficiency in service and repair will of course require instruction and supervised practice on real equipment. Simulation can provide students with an opportunity to develop the basic cognitive skill in an inexpensive way which can systematically lead students from the simple to the complex while allowing for flexibility in the development of understanding.

\section{Rec tions}

The simulation technique can be recommended to teach students in specialized agricultural mechanics courses in secondary schools, in the absence of real equipment or if safety is in question for basic cognitive instruction in dc electricity and hydraulics.

To help better understand the effects of simulation this study should be replicated. Variations of future studies might investigate the influence of abstract reasoning ability or other student variables upon learning and retention. Also, analysis might contain the option using blocking variable such as abstract reasoning level, mechanical aptitude and other variables.

\section{References}

Abrams, M.L. (1974). Acquisition of a psychomotor skill simulated-task, augmented feedback (Evaluation of_a_ welding training simulator) . (Report No. NPRDC-TR-13). San Diego, CA: Navy Personnel Research and Development Center. (ERIC Document Reproduction No. ED 114 584)

Adams, C.K. (1976). Lump detection in simulated human breasts. Perception \& Psychophysics, 20(3), 163-167. (From Psychological Abstracts) 1976, 57, Abstract No. 04832)

Bloom, B.S. (1957). Taxonomy of educational objectives. New York: David McKay Co., Inc.

Cherryholmes, C.H. (1966). Some current research on effectiveness of education simulations. American Behavioral Scientist, $\underline{\mathbf{1 0}}$ (2), 4-7. 
Cohen, R.B.,\& Bradley, R.H. (1978). Simulation games, learning and retention. Elementary School Journal, 78(4), 247-253. (Prom Psychological Abstracts . 1978, 63, Abstract No. 10564)

Isaac, S., \& Michael, W.B. (1983). Handbook in research and evaluation (2nd ed.). San Diego, CA: EDITS Publishers.

Heinkel, O.A. (1970). Evaluation of simulation as a teaching device. Journal of Experimental Education 38(3), 32-34.

Kennedy, J.J. (1978). \&introduction to the design and analysis of experiments in education and psychology. New York: University Press of America.

Lee, J.S. (1979). Program planning guide for agribusiness education. New York: McGraw-Hill, Inc.

Maidment, R. \& Bronstein, R.H. (1973). Simulation Games: Design \& Implementation . (1st ed).

Columbus, Ohio; Charles E. Merrill

McClelland, W.A. (1970). Simulation: Can it benefit vocational education? American Vocational Journal. 45(6), 23-25, 40 .

Newcomb, L.H., McCracken, D. \& Warmbrod, R. (1986). Methods of Teaching Agriculture. Danville, Illinois: Interstate Printers and Publishers

Olivas, L. \& Newstrom, J.W. (1981). Learning through the use of simulation games. Training \& Development Journal, 35(9), 63-66.

Perritt, R.D. (1981). Effects of two instructional techniques used with the power train simulator on the performance of Mississippi vocational agriculture students (Doctoral dissertation, Mississippi State University, 1981). Dissertation Abstracts International, 4 42, 3843.

Pierfy, D.A. (1977). Comparative simulation game research: stumbling blocks and stepping stones. Simulation and Games, 8 , 225-268.

Spitze, H.T. (1980). Instructional materials and techniques. In R.A. Cross (Ed.). Vocational Instruction (AVA Yearbook, 1980 (Pp. 125-132). Arlington, VA: The American Vocational

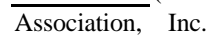

Standard, S.J., and Bode, K.W. (1976). SRA Test of Mechanical Concents: Examiner's Manuzln.. Chicago: Science and Research Associates, Inc. 